\title{
Bringing home the biggest bacon: a cross-site analysis of the structure of hunter-kill profiles in Neotropical forests
}

\author{
Adriano Jerozolimski ${ }^{\mathrm{a}, *}$, Carlos A. Peres ${ }^{\mathrm{b}}$ \\ ${ }^{a}$ Departamento de Ecologia-IB, Universidade de São Paulo, CP 11461, CEP 05422-970, São Paulo - SP, Brazil \\ ${ }^{\mathrm{b}}$ Centre for Ecology, Evolution and Conservation, School of Environmental Sciences, University of East Anglia,
} Norwich NR4 7TJ, UK

Received 29 November 2001; received in revised form 12 September 2002; accepted 13 September 2002

\begin{abstract}
Forest vertebrates are critical to the subsistence of many tropical forest dwellers enjoying little or no access to other sources of animal protein. Yet the ecological and socioeconomic value of forest wildlife is being undermined as many large vertebrate populations are driven to local extinction by unsustainable hunting practices. Although large mammals that are preferred by hunters are widely variable in their morphology and ecology, they share a set of life history traits, which make them particularly vulnerable to overhunting. In this paper we compile data on game harvest from 31 tribal and nontribal settlements in Neotropical forests to examine how mammal assemblages are affected by the history of hunting within settlement catchment areas. The structure of hunter-kill profiles is related to settlement age and size in an attempt to understand how changes in hunting pressure may affect prey selectivity and the structure of residual game assemblages. There was a predictable shift from a few large-bodied to several smallbodied species harvested by increasingly older villages. Settlement persistence thus explained a significant proportion of the variation in mean body mass and species richness of mammals harvested. We conclude that differences in prey species profiles obtained by subsistence hunters of different ethnic groups can be largely explained by the local depletion status of game stocks, particularly large mammals, rather than by cultural factors.
\end{abstract}

(C) 2003 Elsevier Science Ltd. All rights reserved.

Keywords: Bushmeat; Exploitation; Hunting; Large vertebrates; Neotropical forests; Species diversity

\section{Introduction}

Subsistence hunting has been a critical form of protein acquisition for tropical forest dwellers since the earliest Stone Age hunters (Stanford and Bunn, 2001). This is particularly the case for many indigenous, mestizo and colonist communities that remain physically isolated, and have little or no access to other sources of animal protein.

Anthropologists were the first to systematically describe the issue of subsistence hunting by indigenous communities, and record settlement-based information on social and cultural factors that may affect different hunting practices and their outcomes in terms of game vertebrates consumed. In these studies, a settlement

\footnotetext{
* Corresponding author. Tel.: +55-11-3864-0425; fax: +55-113872-7364.

E-mail address: pingo@dialdata.com.br (A. Jerozolimski).
}

sample of hunter-kill records (hereafter, harvest profiles) were often a by-product of a more general investigation on traditional patterns of forest resource use, particularly in relation to diet.

Although the levels of indigenous protein intake often appear to be more than sufficient, the strategies used to maintain them can be extremely variable, reflecting a wide variety of cultural and ethnographic contexts involved in this subsistence activity (Balée, 1985; Beckerman, 1994). Game harvest profiles could thus be affected by feeding taboos against some target species, locally enforced bag limits on numbers of individuals killed, spatial or seasonal restrictions to hunting areas or certain species, limits on the age and sex of individuals of a prey population, and hunting technology in terms of traps and weapons used to capture different target species. However, the distinction between what could be described as culturally selected precautionary practices that may prevent future game shortages and 
mere adaptive responses to a history of local game depletion remains unclear.

Local extinction events in prey species assemblages is a non-random process governed by morphological, metabolic, and reproductive traits, which are usually correlated with body mass (Peters, 1983). Large body size is one of the most frequently cited traits facilitating extinction events, probably because it is associated with low reproductive rates, low population densities, long generation time and long lifespans (Hennemann, 1983; McKinney, 1997). Large game mammals may thus share a set of common life history traits that make them particularly vulnerable to overhunting. The structure of harvest profiles could thus be primarily affected by the availability of large-bodied mammals, which are often preferred game species (Peres, 1990; Alvard, 1993; Bodmer et al., 1994).

In this paper, we attempt to explain differences in the composition and relative abundance of mammal species consumed by neotropical rural folks, using a comprehensive compilation of hunting studies quantifying terrestrial vertebrate kills brought into tribal and nontribal settlements. We provide evidence that a gradual shift from large to small-bodied prey species is widespread and that cultural factors, such as feeding taboos, seem to play a minor role in determining the overall composition of target species. To that end, we relate key parameters summarising game harvest profiles to information on the age and population size of human settlements to examine how the history and scale of hunting could affect the residual mammal assemblage in a given catchment area. Finally, we discuss how prey selection by neotropical subsistence hunters could be affected by ecological rather than socio-cultural constraints.

\section{Methods}

\subsection{Compilation criteria}

Data on neotropical hunting kill records were compiled from the literature, initially on the basis of the seminal review by Redford and Robinson (1987). In addition to all studies incorporated in their analysis, an extensive search of more recently published and unpublished studies was carried out. The following selection criteria were used in compiling these studies: (1) tropical forest was the predominant vegetation type within the hunting catchment area; (2) hunting was conducted exclusively for local subsistence rather than for commercial purposes; (3) the number of individuals and identification of all mammalian species consumed at the settlement surveyed were available; (4) mammalian harvest profiles included a sample size of at least 30 individual kills; (5) the number of consumers (settlement size) and/or age of settlements were available, and (6) significant rates of habitat disturbance had not been reported for any of the settlement catchments.

\subsection{Study settlements}

We compiled game harvest data obtained from 31 settlements in seven South American countries including Bolivia, Brazil, Colombia, Ecuador, Peru, Suriname and Venezuela. The geographic location and a brief description of each study settlement are presented in Fig. 1 and Table 1, respectively. Although forest types were variable across sites-reflecting differences in soil, topography and climate - primary evergreen forest was the predominant vegetation in all sites. Despite the variable importance of seasonally flooded vs. upland forest within settlement catchment areas, all forest sites were dominated by the latter. Catchments encompassing a uniform habitat landscape other than lowland evergreen forest included a low montane forest (site 18) and several sites where the dominant closed-canopy matrix contained patches of mature liana forest (site 24), bamboo forest (sites 4 and 5), and natural savanna (sites 8, 9, 16).

Although different kill profiles were obtained using slightly different hunting methods, hunters in virtually all studies used projectiles deliberately discharged from traditional (bow-and-arrow and blowguns) or fireweapons (shotguns). This is crucial in assessing patterns of prey choice because indirect capture devices such as snares and nets, which are often used in paleotropical forests (Fa and Peres, 2001), result in different selectivities that cannot be easily compared with kills obtained from direct encounters between hunters and potential prey items. Given that our aim is to search for broad patterns of game harvest by subsistence hunters, the distinction between the wide range of ethnic groups sampled by all studies is not of primary significance. However, we checked for differences between colonists and Indians in all variables considered in the analysis because these two major groups can diverge considerably in their hunting practices (Redford and Robinson, 1987). Information on the site location, ethnic group, settlement age, settlement size, duration of the study, and the data source is provided in Table 1. Of the 31 settlements examined here, seven were occupied by nontribal communities of lowland forest dwellers (caboclos, mestizos, and colonists), whereas 24 sites were inhabited by Indian communities (sensu strictu) belonging to 20 different ethnic groups.

Information on the size and age of settlements was recorded from each study and used as proxy variables of the intensity and persistence of hunting activities within each catchment area. There was no clear relationship between settlement age and settlement size $(r=0.16$, $P=0.41, n=27$ ), so these two variables could be used independently in a multiple regression model to examine 


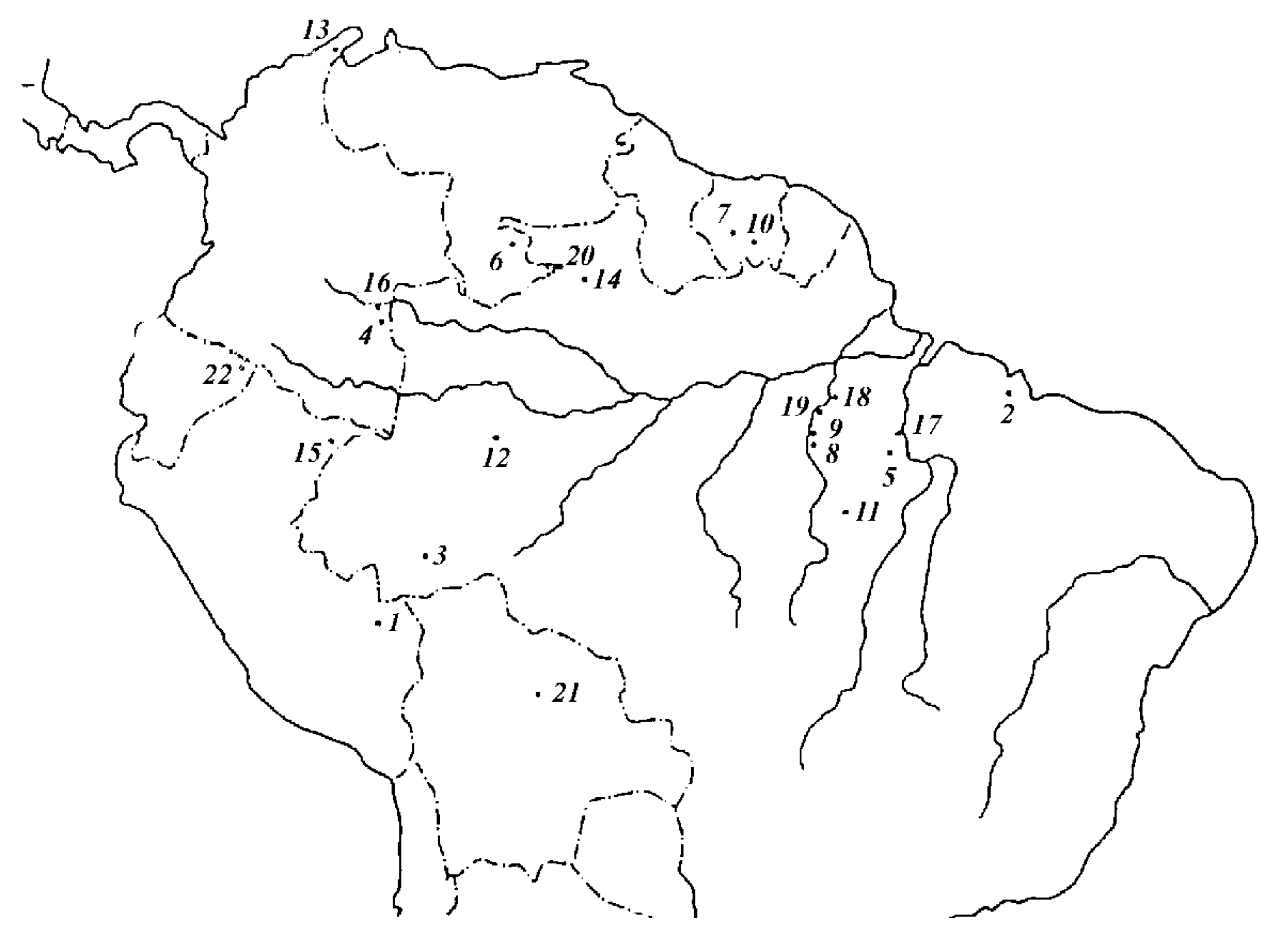

Fig. 1. Location of South American sites considered in this study. Locality numbers refer to game harvest profiles listed in Table 1.

their effects on the structure of harvest profiles in terms of mean mammal body mass and mammal species richness.

\subsection{Game harvest profiles}

The body mass for every mammal consumed was recorded using the mean body weight available for adults of each species from the literature in order to standardise comparisons between sites. This was necessary because weights of individual carcasses (or the aggregate biomass of all dressed or undressed carcasses of a given species) were not provided in several studies. Body mass data were extracted from Smith and Jungers (1997) for primates and from Emmons and Feer (1990) for other mammalian orders.

We focus on mammals when comparing harvest profiles because this class of vertebrates is by far the most important to tropical forest subsistence hunters worldwide (Robinson and Bennett, 2000), and they have been most consistently reported and better identified across all neotropical hunting studies. Moreover, this partially controls for potential effects of phylogeny on extinction vulnerability (McKinney, 1997) by restricting the analysis to a single class of vertebrates. However, we explicitly considered the relative importance of the aggregate mammal biomass in each harvest profile compared to that of all other (avian and reptilian) terrestrial prey items by also incorporating this variable into our predictive models.

We attempted to validate the now widely held view that subsistence hunters prefer large-bodied species
(Smith, 1976; Ayres and Ayres, 1979; Hames, 1979; Hames and Vickers, 1982; Peres, 1990) and that their availability is affected by settlement history and reflected in real-world harvest profiles. Hunters attempt to maximise their net benefit (amount of meat harvested per unit of hunting effort) by bypassing a number of small vertebrate species and selectively targeting comparatively fewer large-bodied species whenever possible (Alvard, 1993; Bodmer, 1995). If large-bodied species are selectively killed whenever they become available, then their conspicuous absence in a harvest profile or high consumption rates of small-bodied species, could be interpreted as evidence of depletion of preferred species.

A hunter selectivity analysis considering the body mass of target species was therefore conducted for five sites where both harvest profiles and population density estimates for game species were available (sites 1, 5, 7, 11 and 16). Selectivity was calculated using the Ivlev's Selectivity Index, which ranges from -1.0 to 1.0 and compares availability (A) with utilisation (U) by $(\mathrm{U}-\mathrm{A}) /(\mathrm{U}+\mathrm{A})$ (Bodmer, 1995).

\subsection{Assumptions}

We assume that a similar spectrum of mammalian body sizes was originally represented at all sites, making the original source fauna roughly comparable across studies. Although this information is unavailable for some sites, large-bodied mammals including all ungulates, caviomorph rodents, and the ateline primates $(>4$ $\mathrm{kg}$ ) appearing in different harvest profiles are either ubiquitous in their geographic occurrence throughout 
Table 1

Summary information for the studies on the 31 settlements compiled here, which are indicated at 22 sites and numbered (in parentheses) as in Fig. 1

\begin{tabular}{|c|c|c|c|c|}
\hline $\begin{array}{l}\text { Settlement } \\
\text { number }\end{array}$ & Group (Location) & $\begin{array}{l}\text { Settlement age } \\
\text { (years)/human } \\
\text { population size }\end{array}$ & $\begin{array}{l}\text { Duration of } \\
\text { data collection } \\
\text { (days) }\end{array}$ & Sources \\
\hline $1(1)$ & Piro - settlement of Diamante (Southeastern Peru) & $\geqslant 25 / 247$ & 540 & Alvard, 1993, 1995; Alvard et al., 1997 \\
\hline $2(2)$ & Ka'apor-site 1 (Northeastern Brazil) & $6 / 27$ & 51 & Balée, 1984, 1985 \\
\hline $3(2)$ & Ka'apor-site 2 (Northeastern Brazil) & $12 / 72$ & 47 & Balée, 1984, 1985 \\
\hline $4(3)$ & Mestizo - river bank (Western Brazil) & $\geqslant 25 / 229$ & 360 & Calouro, 1995 \\
\hline $5(3)$ & Mestizo - interior (Western Brazil) & $\geqslant 25 / 212$ & 360 & Calouro, 1995 \\
\hline $6(4)$ & Tatuyo-Yapu (Southeastern Colombia) & $14 / 110$ & 107 & Dufour, 1981 \\
\hline $7(5)$ & Parakanã (Central Brazil) & $12 / 265$ & 360 & Emidio-Silva, 1998 \\
\hline $8(6)$ & Yanomami (Southern Venezuela) & $5 / 51$ & 216 & Hames, 1979; Hames and Vickers, 1982 \\
\hline $9(6)$ & Ye'kwana (Southern Venezuela) & $5 / 76$ & 216 & Hames 1979; Hames and Vickers, 1982 \\
\hline $10(7)$ & Trio (Southwestern Suriname) & $20 / 450$ & 30 & Lenselink, 1972 \\
\hline $11(3)$ & Mestizo (Western Brazil) & $\geqslant 25 / 405$ & 360 & Martins, 1992 \\
\hline $12(8)$ & Arara (Northern Brazil) & $? / 90$ & 85 & Milton, 1991 \\
\hline $13(9)$ & Arawete (Northern Brazil) & $? / 110$ & 28 & Milton, 1991 \\
\hline $14(4)$ & Maku (Northwestern Brazil) & $? / 690$ & 52 & Milton, 1984 \\
\hline $15(10)$ & Suralco (Suriname) $)^{\mathrm{a}}$ & $4 / 25$ & 89 & Mittermeier, 1991 \\
\hline $16(11)$ & Kayapo-A'ukre (Southeastern Brazilian Amazonia) & $19 / 200$ & 525 & Nascimento, 1999 \\
\hline $17(12)$ & Mestizo - Vila Moura (Northern Brazil) & $20 / 81$ & 877 & C. Peres, unpublished data \\
\hline $18(13)$ & Irapa-Yukpa (Northwestern Venezuela) & $\geqslant 25 / 64$ & 206 & Paolisso and Sackett, 1985 \\
\hline $19(14)$ & Hupdu Maku (Northwestern Brazil) & $\geqslant 25 / 75$ & 168 & Reid, 1979 \\
\hline $20(15)$ & Matses (Northeastern Peru) & $7 / 549$ & 240 & Romanoff, 1984 \\
\hline $21(20)$ & Yanomami-interior (Northwestern Brazil) & $4 / 67$ & 51 & Saffirio and Scaglion, 1982; Saffirio and Hames, 1983 \\
\hline $22(16)$ & Maku (Eastern Colombia) & $2 / 84$ & 270 & Silverwood-Cope, 1972 \\
\hline $23(17)$ & Mestizo-Nova Fronteira settlement (Northern Brazil) & $2 / 204$ & 360 & Smith, 1976 \\
\hline $24(18)$ & Mestizo - Leonardo da Vinci settlement (Northern Brazil) & $2 / 179$ & 268 & Smith, 1976 \\
\hline $25(19)$ & Mestizo - Coco Chato settlement (Northern Brazil) & $15 / 351$ & 330 & Smith, 1976 \\
\hline $26(20)$ & Sanema (Southeastern Venezuela) & $? / 33$ & 120 & Sponsel, 1981 \\
\hline $27(21)$ & Yuqui-1983 ${ }^{\mathrm{b}}$ (Eastern Bolivia) & $18 / 73$ & 56 & Stearman, 1990; Stearman and Redford, 1995 \\
\hline $28(21)$ & Yuqui-1988 ${ }^{\mathrm{b}}$ (Eastern Bolivia) & $23 / 103$ & 80 & Stearman, 1990; Stearman and Redford, 1995 \\
\hline $29(21)$ & Siriono-Ibiato settlement (Eastern Bolivia) & $\geqslant 25 / 500$ & 360 & Townsend, 2000 \\
\hline $30(22)$ & Siona-Secoya (Northeastern Ecuador) & $2 / 132$ & 283 & Vickers, 1980, 1991 \\
\hline $31(22)$ & Waorani (Northeastern Ecuador) & $\geqslant 25 / 230$ & 275 & Yost and Kelley, 1983 \\
\hline
\end{tabular}

a Location of this study may be approximate due to lack of precise geographical information;

b More than one harvest sample obtained over a time span of 5 years was considered for these study sites because age and size of settlements differed substantially between the first and subsequent sample.

Amazonia and the Guyana shield, or are replaced by congeners or similar species belonging to ecologically equivalent genera (Emmons and Feer, 1990; Eisenberg and Redford, 1999). Indeed, the broad scale distribution of the most common large-bodied species consumed encompassed virtually all sites. In the case of primates, the occasional absence of a particular genus in the species pool of a settlement catchment was always replaced by an equivalent genus with similar body size (e.g. Ateles and Lagothrix: Peres and Janson, 1999).

We also assumed that the duration of each study incorporated into this comparative analysis was sufficient to assess the local availability of large-bodied game. We therefore excluded all harvest profiles with fewer than 30 kills, which could have resulted from excessively brief sampling periods or a small number of households sampled.

Finally, due to the lack of precise information on the age of some of the oldest settlements, we truncated settlement age to a maximum of 25 years. We therefore assumed that 25 years of settlement persistence at a given site is sufficiently long to allow its game community to respond to the local history of hunting and that responses to additional hunting pressure thereafter are comparatively unimportant.

\section{Results}

Settlements examined here were on average 193 strong $($ S.D. $=169.9$, range $=25-690$ inhabitants, $n=31)$ and had been established from 2 to 25 years (mean \pm S.D. $=15.9 \pm 9.2$ years, $n=27$ ) prior to each study. The total length of these studies varied from 28 to 877 days (237.7 \pm 187.5 days), and they recorded an average number of $259 \pm 383$ mammal kills (range $=30-1780$ ) belonging to as few as seven and as many as 24 mammal species (mean $=14.5 \pm 5.4$ species).

The seven colonist settlements considered here did not differ from the 24 Indian settlements in terms of age, size, relative importance of mammals, mean body mass of mammals consumed, and number of mammal species consumed (Mann-Whitney U, $P>0.3$ in all cases). However, the total duration of Indian settlement studies (186 \pm 149 days) was shorter than those of colonist settlements $(416 \pm 206$ days; $P=0.025)$. 
Exclusive use of traditional weapons was recorded in only four of the 24 indigenous settlements considered here (settlements 9, 12,13, and 14), and traditional weapons were the most important in terms of game biomass harvested in two other settlements (21 and 31) where hunters also used shotguns. The total duration of studies where hunters used mainly traditional weapons (117 \pm 102 days) was shorter than that in settlements using fireweapons $(287 \pm 197$ days; $P<0.05)$. However, these differences are unlikely to affect our results because the duration of the studies included in the analysis was probably long enough to sample the mammal species available in a catchment. Moreover, there were no differences in all other variables (settlement age and size, relative importance of mammals, mean body mass of mammals consumed, and number of mammal species consumed) between settlements using primarily fireweapons and those using traditional weapons (MannWhitney $\mathrm{U}, P>0.2$ in all cases).

Therefore, considering the scope of the analysis, we make no further distinctions between native aborigines and colonists, nor between hunters using traditional and modern weapons, which in many ways converged entirely in their prey acquisition practices.

\subsection{Prey species selectivity}

The five settlements $(1,5,7,11$ and 16) at which both population census and harvest data allowed us to examine hunter selectivity had human population sizes ranging from 200 to 405 inhabitants who had been settled for 12-25 years. Hunters at these sites exhibited a clear bias towards large-bodied target species, showing an abrupt transition from negative to positive Ivlev's index of selectivity values as the size of prey species increased (Fig. 2). Assuming a linear relationship, body mass of mammals harvested explained $41.3 \%$ of the overall variation in selectivity $(r=0.64, n=76$, $P<0.001$ ), and mammal species larger than $6.5 \mathrm{~kg}$ (giant armadillos, pacas, atelinae primates and ungulates) were almost invariably associated with highly positive selectivity values on the basis of their local population density. In contrast, smaller-bodied mammals harvested at the same sites were largely associated with negative selectivity values, presumably because they were often ignored and bypassed by hunters searching for larger prey.

\subsection{Correlates of prey size}

The mean body mass of mammals consumed at each settlement was widely variable, ranging from a minimum of 5.2 to a maximum of $42.7 \mathrm{~kg}$ (mean $=16.9 \pm 9.3$ $\mathrm{kg}, n=31$ ). The number of mammal species consumed also ranged widely from 7 to 24 species (mean $=14.6 \pm 5.4, n=31$ ), despite the fact that a similar set of game species occurred at all sites. We found a weak correlation between settlement size and mean body mass of game species harvested $(r=0.19, n=31$, $P=0.31$, indicating that larger settlements did not necessarily drive down the size of their kills. However, there was a clear negative correlation between the age of settlements and the mean body mass of mammal kills consumed ( $r=0.41, n=27, P<0.05$; Fig. 3a), suggesting that large-bodied mammalian prey items were more likely to be harvested by hunters from recent settlements. Indeed, the mean body mass of mammals consumed after 10 years of hunting activity within the catchment area of given settlement was reduced by $4 \mathrm{~kg}$ (Beta coefficient $=-0.41$ ). This was confirmed by a multiple regression model (backward stepwise elimination procedure; $\left.r^{2}=0.39, n=27\right)$ in which the average body mass of mammals harvested was significantly depressed by settlement age (Beta coefficient $=-0.53$, $P=0.004$ ), whereas settlement size (number of consumers), the relative importance of mammalian prey compared to other classes of terrestrial vertebrates, and length of each study were excluded from the model (alpha-to-remove $=0.15$ ).

\subsection{Correlates of the number of species consumed}

We found only a weak correlation between the species richness of mammals consumed and the number of consumers in a given settlement $(r=0.14, n=31$, $P=0.44$, again suggesting that larger settlements per se did not necessarily result in less selective kill profiles. However, there was a clear positive relationship between settlement age and the species richness of mammal kills $(r=0.67, n=27, P<0.001$; Fig. $3 b)$, indi-

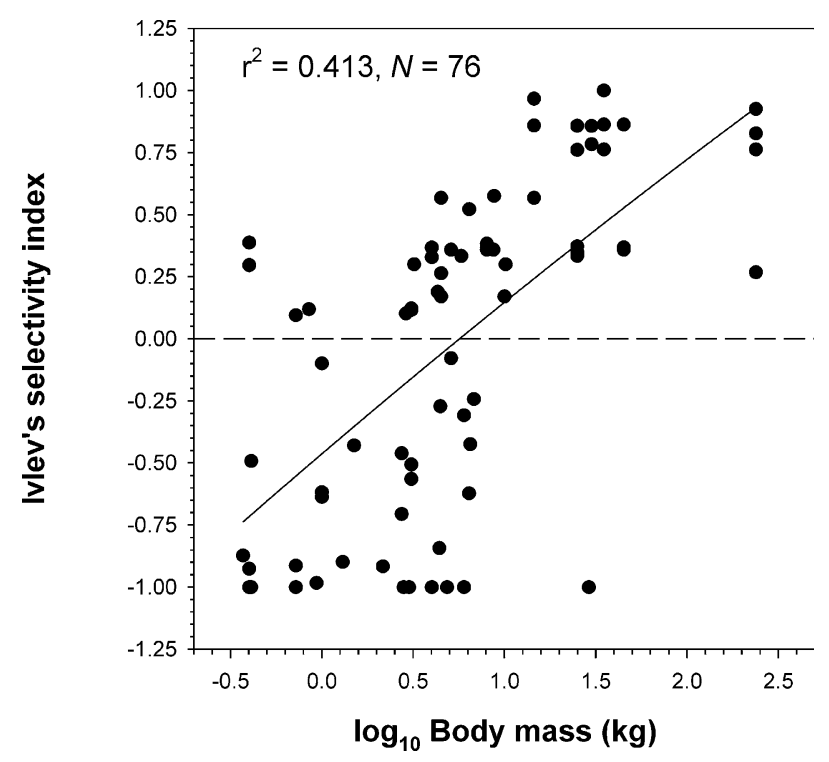

Fig. 2. Relationship between mammal body mass and Ivlev's index of selectivity for five study areas (settlements 1, 5, 7, 11 and 16). Positive and negative selectivity values are separated by dashed line. 

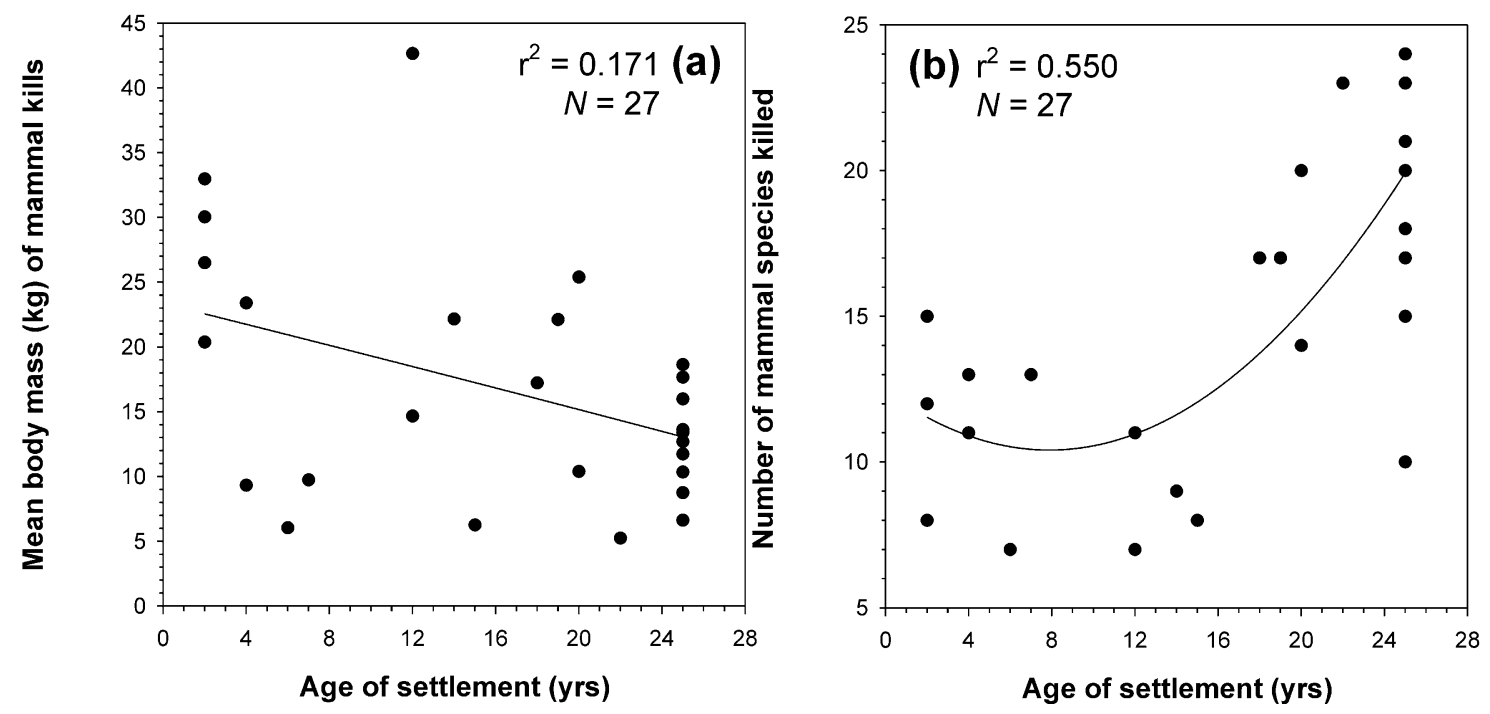

Fig. 3. Relationship between age of settlement and (a) mean body mass of mammalian kills consumed; and (b) number of mammal species consumed. Regression lines represent best-fit models.

cating that hunters in increasingly older settlements may have been forced to resort to a larger number of prey species. However, this response is apparently nonlinear, with hunters beginning to diversify their prey portfolio after a catchment area had been persistently harvested for about 15 years. On average, villagers in a given settlement consumed nearly seven additional mammal species - that had not been previously consumed during the early post-settlement period-after their catchment had been chronically harvested for 10 years (Beta coefficient $=0.67)$. This relationship does not appear to be an artefact of sampling heterogeneity in that it was not affected by the duration of different studies; the number of species detected in a kill profile did not necessarily increase in longer studies $(r=0.24, n=31$, $P=0.19$ ).

Indeed, length of study, the relative importance of mammalian prey, and number of consumers within a settlement were all eliminated from a multiple regression model (alpha-to-remove $=0.15$ ) considering the collective effects of these variables on prey species richness. Settlement age was the only variable retained by the model (Beta coefficient $=0.403$ ) following three iterative steps $\left(r^{2}=0.453, n=27\right)$.

\section{Discussion}

A number of studies have shown that tropical forest hunters have a narrow range of preferred species that will be targeted whenever possible, regardless of their local abundance and extinction probability (Hawkes et al., 1982; Vickers, 1991; Bodmer, 1995; Fa and Peres, 2001). As predicted by optimal foraging theory, this preference is consistently skewed towards larger species yielding the greatest amount of meat per unit of energy or time allocated. For instance, the cost of shotgun cartridges for hunters wielding fire-weapons, or of preparing handmade projectiles for traditional weapons, seems to be a constraint forcing hunters to maximise the amount of meat obtained per unit of ammunition spent. Hunters from the five sites at which both harvest profiles and game density estimates were available, showed a significantly higher degree of preference for large mammal species (Fig. 2). The small $r^{2}$-value of the regression model, however, has to be interpreted in light of the fact that these five settlements were relatively large and old. One could therefore expect that hunters at these catchments could no longer afford to be as selective as during the early post-settlement period when the probability of encountering large mammals was likely to be much higher. A stronger relationship might have been found had we been able to obtain these data from relatively young, small settlements. For instance, mammalian body mass explained $83 \%$ of the variation in prey selectivity for the youngest of the five settlements considered, a $r^{2}$-value almost two-fold greater than that obtained for all settlements combined.

As a consequence of the heavier hunting pressure on large-bodied mammals, gradual, if not sudden, population declines can be expected for these species because they bear the brunt of the initial offtake and tend to recover slowly from a selective harvest, mainly due to low reproductive rates (Bodmer, 1995). Many studies have reported highly significant differences in large vertebrate population densities between hunted and nonhunted sites (Martins, 1992; Bodmer, 1995; Alvard et al., 1997; Mena et al., 2000; Peres, 1990, 2000a). These population declines will reach a threshold whereby exploiting a greater range of smaller, less preferred species will result in a higher return, thus shifting prey selection to these species. Indeed, greater exploitation 
rates of small mammals, such as echimyid rodents and didelphid marsupials, occurs only after large game such as tapir, peccaries, and large primates have been severely depleted (Smith, 1976; Ayres and Ayres, 1979; Hames and Vickers, 1982; Stearman and Redford, 1995; C. Peres, unpubl. data). For example, the high trapping effort that some permanent settlements in Peru (Hiraoka, 1995) and Ecuador (Suárez et al., 1995) allocate to small mammals seems to be a response to large game depletion.

Our findings that the reduction in mean body size of mammals consumed is concomitant with an increase in game species richness provide further evidence that the increased utilisation of smaller species is a consequence of large game depletion. An increase in the offtake of less preferred species that had not been previously bypassed by hunters on foot would be, therefore, a result of changes in hunter selectivity.

The data presented here, however, includes a number of uncontrolled sources of variation as discussed below, which could account for the low predictive power of the analysis. Nevertheless, the depletion of large vertebrate populations due to persistent hunting pressure, reflected in the smaller mean size and higher species richness of game consumed, seems reasonably clear. In the future, this pattern could become even more ubiquitous in large remaining tracts of tropical forests as the motivation and opportunities for village resettlement events become prohibitive due to socio-political, land tenure, and infrastructure factors encouraging prolonged sedentarism. This will clearly undermine the source-sink dynamics of game populations recolonizing previously overharvested areas (Peres, 2001), which could garantee a sustainable harvest at a landscape-scale

\subsection{Possible sampling biases}

Harvest profiles obtained here used different sampling methods, including daily or weekly interviews and monitoring of hunting forays and kills brought back from the forest at the settlement or household level. These studies were conducted to test different hypotheses and by observers with different backgrounds, including local field assistants, anthropologists, and wildlife biologists, resulting in differences in the taxonomic refinement of species identification. It could also be argued that in some cases interviewees would be more likely to overlook (or fail to report) the consumption of small-bodied, less important species. Consequently, interview-based samples obtained through mental recollection of previous game consumption could be intrinsically biased towards large-bodied species. This, however, is a minor problem because this study is primarily concerned with the capture of large game (or the lack thereof) and, in any case, this is likely to be a systematic bias in the same direction.

\subsection{Taboos, restrictions, injunctions and rituals}

Strong cultural or social factors regulating prey choice could seriously confound interpretations of the composition and relative abundance of game species captured as a representative sample of the local game stock. However, feeding taboos and restrictions could switch "on" and "off" depending on levels of game depletion (Ross, 1978). This is consistent with the process of de-tabooing species that were once tabooed, as the case of the "de-tabooed" deer among the SionaSecoya (Hames and Vickers, 1982). In the Yuqui community of Bolivia, the increased consumption of meat previously considered to be undesirable (Stearman, 1990), such as kinkajous (Potos flavus) and coatis (Nasua nasua), is evidence of the minor role played by cultural factors when large game species become scarce. Even the intrinsic desirability of different species appears to be context-dependent in terms of the local availability of animal protein. For instance, many caboclo communities in increasingly overhunted areas of Brazilian Amazonia now consume several midsized to small-bodied game species previously thought to be unpalatable or undesirable; by the same token, hunters who are heavily subsidised by a super-abundance of aquatic sources of protein or livestock meat often bypass game species that are perfectly acceptable elsewhere, and may provide irrational explanations for doing so (C. Peres, pers. obs.). Finally, feeding taboos could be just a strategy to prevent hunters from wasting time searching for game species that are difficult to find, thus reflecting the relative costs of obtaining different prey species, as in the case of tapir (Tapirus terrestris) and deer (Mazama sp.) tabooed amongst the Achuara Jivaro (Ross, 1978).

\subsection{Settlement size}

Since large settlements require large game offtakes, it is reasonable to expect that hunting pressure will become heavier in such contexts if a proportional increase in the catchment area does not follow (Alvard et al., 1997). Alvard (1995) suggests that the differences between the degree of faunal depletion near the Piro village of Diamante and the Machigenga village of Yomiwato of southern Peru were primarily due to a larger human population size rather than the use of shotguns. Vickers (1980) also suggests that the availability of protein resources may be a limiting factor on community size, but stressed that a multi-factorial model is likely to prove more useful in the investigation of tropical forest cultural adaptation.

In this study, the weak relationship between settlement size and the size distribution and species richness of mammals consumed may have partly resulted from the dynamic nature of consumer numbers throughout 
the settlement history which was not reported in most studies. Events such as settlement fission and fusion, and differences in population growth rates, migratory movements, and household-level or per capita rates of game consumption could all play a part.

\subsection{Size of catchment area and hunting technology}

Because all human groups considered here share similar energetic constraints in moving through their environment, one would expect no significant differences between catchment areas. However, differences in per capita consumption of animal protein can affect the time allocated to protein acquisition as well as the size of the catchment area used. Although most centralplace hunting practices typically occur within a 6-12 km radius of a settlement (Jorgensen, 1995; Peres, 2001), the practice of prolonged forays to distant hunting areas clearly affects the harvest profile, confounding the impact of settlement history on the size structure of local game assemblages. Settlement age should thus become an even stronger predictor of shifts in harvest profiles if the effects of catchment area could be controlled for. Information on the size of catchment areas could not be considered here because it was not sufficiently realiable for several sites. The use of modern transportation technology such as motorised boats also affects hunter mobility within indigenous territories blurring the effects of central-place hunting on local faunal assemblages from the perspective of hunter-kill profiles. This was clearly the case of the Parakanã Indian settlement of Paranatinga (Emídio-Silva, 1998) whose large body mass of mammal kills was an outlier well above the regression line in Fig. 3a. Hunters from this settlement use trucks and motor boats to reach distant hunting grounds subjected to low hunting pressure, and where the density of large mammals is much higher. This strategy is also practiced by the Waimiri-Atroari of central Amazonia (Souza-Mazurek et al., 2000) and the Kayapó of southeastern Amazonia (A. Jerozolimski, pers. obs.), as well as several other Indian groups who use increasingly more affordable motorised transport.

Although the introduction of shotguns clearly leads to significant increases in hunting efficiency, its consequences for the overall meat consumption is not straightforward. For the Waorani of Ecuador, it indeed results in a $33 \%$ increase in the amount of meat consumed (Yost and Kelley, 1983). However, the introduction of shotguns did not lead to an increase in the amount of meat consumed at the Piro community of Diamante, Peru (Alvard, 1995), and the Siona-Secoya of Ecuador, where an increase in hunting efficiency resulted in a greater amount of time allocated to other economic activities such as agriculture (Hames, 1979).

The efficiency of shotguns also depends on the size and behaviour of the target species. For large mammals, shotguns are indisputably superior, but for small-bodied species and those moving in large groups, traditional weapons may be more effective. The silent use of blowguns allows the hunter to kill multiple group-members before the group disperses (Yost and Kelley, 1983; Peres, 1990). However, the nearly universal substitution of traditional weapons by shotguns in aborigine societies provides the best indication yet of the inevitable technological transition to modern hunting technology. Indeed, the use of shotguns was recorded in all recent studies included in this analysis, and all four indigenous settlements which did not use modern weapons were studied before 1986.

\subsection{Differences in the source fauna}

Since the sites covered in this study shared a similar pool of game species that are widely distributed across Amazonia and the Guianan shields, differences in game composition were rather unimportant in the analysis (c.f. Redford and Robinson, 1987). Primates are the mammalian order showing the greatest variation in local species composition, but the overall size spectrum of different primate assemblages remained largely constant (Peres and Janson, 1999).

Temporal changes in population density could be another source of variation, but little is known about this. Hill et al. (1984) stated that, for the Aché of eastern Paraguay, there is no significant variation in the amount of meat consumed from season to season. They also suggest that other low-latitude groups will show even less seasonality in resource consumption. However, there are several studies showing fluctuations in game yields throughout the year, which could be a result of both fluctuations in the availability of game and aquatic sources of protein, and environmental differences affecting game detectability (Yost and Kelley, 1983; Emídio-Silva, 1998; Nascimento, 1999).

\subsection{Availability of other sources of animal protein}

Hunting pressure is likely to be inversely correlated with the availability of animal protein other than terrestrial game species. In these terms, a settlement close to a highly productive river and enjoying a reliable source of fish would be less reliant on forest wildlife than those deprived of this resource (Ross, 1978; Calouro, 1995). Although a few tribal communities of native Amazonians may acquire as much as $45 \%$ of their protein from fish, for most upland communities fish may be highly seasonal and contributes only $20 \%$ or less of their protein intake (Balée, 1985). This is understandable given that, since the earliest days of European conquest, Indian settlements along virtually all major Amazonian rivers have been decimated or displaced inland towards less productive headwater 
regions, and a vast proportion of fish stocks are now exploited by artisanal or commercial fisheries controlled by modern Amazonians. All settlements considered here were thus heavily reliant on forest wildlife to a varying degree, and the importance of terrestrial vertebrates other than mammals was explicitly considered in our models.

\subsection{Density compensation and predator relaxation}

Density-dependent mechanisms could affect the population of some target species, and competitive releases could lead to density compensation or undercompensation within and across functional groups. The absence of top predators such as jaguars (Panthera onca) in the mammal community of Barro Colorado Island, Panama, may be associated with a 10-fold increase in the densities of primary consumers such as peccary (Tayassu spp.), paca (Agouti paca) and coati (Nasua narica) (but see Wright et al., 1994). Freese et al. (1982) noted that tamarins (Saguinus spp.) appear to have become more common in some overhunted areas where large monkeys had been exterminated, but this could be partly a function of other environmental gradients (Peres and Dolman, 1999). The Yuqui community of Bolivia significantly increased their consumption of $A$. paca during two sampling periods separated by 5 years (Stearman, 1990), but this could have been a consequence of locally augmented paca densities due to changes in both habitat disturbance from slash-and-burn agriculture and rates of natural predation from ocelots. Moreover, lower encounter rates of target species close to settlements could be a result of target species being more wary of hunters rather than declines in population densities due to local hunting pressure (Hill et al., 1997).

\section{Conclusions}

We have provided evidence that changes in the structure of mammal assemblages due to game hunting, as seen from the perspective of kill-profiles obtained by subsistence hunters, is a widespread phenomenon in Neotropical forests. This is consistent with estimates of the residual game abundance at forest sites subjected to varying degrees of hunting pressure, where overhunting often results in vertebrate biomass collapses, mainly through declines and local extinctions of large-bodied mammals (Bodmer, 1995; Peres, 2000a,b). Moreover, cultural factors such as feeding taboos seem to play a secondary role in changes in the composition and relative abundance of target species recorded in harvest profiles.

Furthermore, the length of time that a catchment area is harvested is a key predictor of the structure of harvest profiles. The gradually larger number of species consumed over time appears to be one of several strategies used to compensate for the decrease in capture rates of large-bodied target species, even in catchment areas surrounded by vast tracts of non-hunted undisturbed forests. In these terms, the animal protein needs of a human settlement - that was once supplied primarily by a few midsized to large-bodied species - tends to shift to smaller species that had not been previously hunted.

These results confirm the notion that exploitation of resource stocks of varying degrees of profitability is non-random and tends to track the availability of a nested subset of increasingly resilient species, which in size-graded vertebrate assemblages is largely correlated with body size. This reinforces previous studies showing that large forest vertebrates, a disproportionately important component of the neotropical megafauna, merit special conservation attention, due to their high susceptibility to overhunting.

The long-term persistence of the original complement of game populations within vast tracts of unprotected tropical forests remains questionable at a time when the aesthetic, ecological, nutritional, economic and cultural value of game vertebrates is finally being recognised. Evaluating the sustainability of modern hunting practices is of paramount importance to the full biotic integrity of extractive, indigenous, and sustainable development reserves.

Management policy from either government agencies or community-based initiatives should explicitly aim to retain those specially vulnerable large vertebrates within large mosaics of harvested and unharvested areas. Game management programs in potentially overhunted areas through bag limits, no-take areas, and perhaps livestock substitution may therefore become inescapable options if we are to prevent the haemorrhage of wildlife resources from tropical forests inhabited by growing and increasingly sedentary human populations.

\section{Acknowledgements}

We thank the authors of all hunting studies compiled here. Two of the unpublished harvest studies included in this analysis were funded by a grant from the Center for Applied Biodiversity Science of Conservation International to CAP. We thank Renata Pardini, Anina Carkeek and the participants of the 3rd Course of Quantitative Ecology and Conservation Biology at the Instituto de Pesquisas Ecológicas (IPE) for valuable comments on this manuscript. Financial support for AJ was provided by a Wellcome Trust studentship (51504/ Z/97/Z) and FAPESP (99/09988-0).

\section{References}

Alvard, M.S., 1993. Testing the "ecologically noble savage" hypothesis: interspecific prey choice by piro hunters of Amazonian Peru. Human Ecology 21, 355-387. 
Alvard, M., 1995. Shotguns and sustainable hunting in the neotropics. Oryx 29, 58-66.

Alvard, M., Robinson, J.G., Redford, K.H., Kaplan, H., 1997. The Sustainability of subsistence hunting in the neotropics. Conservation Biology 11, 977-982.

Ayres, J.M., Ayres, C., 1979. Aspectos da caça no alto rio Aripuanã. Acta Amazonica 9, 287-298.

Balée, W., 1984. The Persistence of Ka'apor Culture. PhD Thesis, Columbia University, New York.

Balée, W., 1985. Ka'apor ritual hunting. Human Ecology 13, 485-510.

Beckerman, S., 1994. Hunting and fishing in Amazonia: hold the answers, what are the questions? In: Roosevelt, A. (Ed.), Amazonian Indians: From Prehistory to the Present. Arizona University Press, Tucson, pp. 177-202.

Bodmer, R.E., Fang, T.G., Moya, L., Gill, R., 1994. Managing wildlife to conserve amazonian forests: population biology and economic considerations of game hunting. Biological Conservation 67, 29-35.

Bodmer, R.E., 1995. Managing Amazonian wildlife: biological correlates of game choice by detribalized hunters. Ecological Applications 5, 872-877.

Calouro, A.M., 1995. Caça de subsistência: sustentabilidade e padrões de uso entre seringueiros ribeirinhos e não-ribeirinhos, Estado do Acre (Brasil). MSc Thesis, Universidade de Brasília, Brasília, Brazil.

Dufour, D.L. 1981. Household Variation in Energy Flow in a Population of Forest Horticulturalists. PhD Thesis, University of New York at Binghamton.

Eisenberg, J.F., Redford, K.H., 1999. Mammals of the Neotropics, Vol. 3. University of Chicago Press, Chicago.

Emidio-Silva, C., 1998. A caça de subsistência praticada pelos índios Parakanã (sudeste do Pará): características e sustentabilidade. Biologia Ambiental. MSc Thesis, Universidade Federal do Pará and Museu Emilio Goeldi, Belém.

Emmons, L.H., Feer, F., 1990. Neotropical Rainforest Mammals: A Field Guide. The University of Chicago Press, Chicago.

Fa, J.E., Peres, C.A., 2001. Game vertebrate extraction in African and Neotropical forests: an intercontinental comparison. In: Reynolds, J.D., Mace, G.M., Redford, K.H., Robinson, J.G. (Eds.), Conservation of Exploited Species. Cambridge University Press, Cambridge, pp. 203-241.

Freese, C.H., Heltne, P.G., Castro, N., Whitesides, G., 1982. Patterns and determinants of monkey densities in Peru and Bolivia, with notes on distributions. International Journal of Primatology 3, 53-90.

Hames, R.B., 1979. A Comparison of the efficiencies of the shotgun and the bow in neotropical forest hunting. Human Ecology 7, 219-252.

Hames, R.B., Vickers, W.T., 1982. Optimal diet breadth theory as a model to explain variability in Amazonian hunting. American Ethnologist 9, 358-378.

Hawkes, K., Hill, K., O'Connell, J.F., 1982. why hunters gather: optimal foraging and the Aché of Eastern Paraguay. American Ethnologist 9, 379-398.

Hennemann, W.W., 1983. Relationship among body mass, metabolic rate and intrinsic rate of natural increase in mammals. Oecologia 56, 104-108.

Hill, K., Hawkes, K., Hurtado, M., Kaplan, H., 1984. Seasonal variance in the diet of Aché hunter-gatherers in Eastern Paraguay. Human Ecology 12, 101-135.

Hill, K., Padwe, J., Bejyvagi, C., Bepurangi, A., Jakugi, F., Tykuarangi, R., Tykuarangi, T., 1997. Impact of hunting on large vertebrates in the Mbaracayu Reserve, Paraguay. Conservation Biology $11,1339-1353$.

Hiraoka, M., 1995. Aquatic and land fauna management among the floodplain riberenos of the Peruvian Amazon. In: Nishizawa, T., Uitto, J.I. (Eds.), The Fragile Tropics of Latin America: Sustainable Management of Changing Environments. United Nations University, Tokyo, pp. 201-225.
Jorgenson, J.P., 1995. Maya subsistence hunters in Quintana Roo, Mexico. Oryx 29, 49-57.

Lenselink, J., 1972. De Jachtopbrengst in een Surinaams Trio-dorp. De Surinaamse Landbouw, Paramaribo 20, 37-41.

Martins, E., 1992. A caça de subsistência de extrativistas na Amazônia: sustentabilidade, biodiversidade e extinção de espécies. MSc Thesis, Universidade de Brasília, Brasília.

McKinney, M.L., 1997. Extinction vulnerability and selectivity: combining ecological and paleontological views. Annual Review of Ecology and Systematics 28, 495-516.

Mena, V.P., Stallings, J.R., Regalado, B.J., Cueva, L.R., 2000. The sustainability of current hunting practices by the Huaorani. In: Robinson, J.G, Bennett, E.L. (Eds.), Hunting for Sustainability in Tropical Forests. Columbia University Press, New York, pp. 57-78.

Milton, K., 1984. Protein and carbohydrate resorces of the Maku Indians of Northwestern Amazonia. American Anthropologist 86, 7-27.

Milton, K., 1991. Comparative aspects of diet in Amazonian forestdwellers. Philosophical Transactions of the Royal Society, London 334, 253-263.

Mittermeier, R.A., 1991. Hunting and its effects on wild primate populations in Suriname. In: Robinson, J.G., Redford, K.H. (Eds.), Neotropical Wildlife Use and Conservation. The University of Chicago Press, London, pp. 93-107.

Nascimento, H.S. 1999. Hunting Sustainability by Kayapó Indians of A-Ukre Village, Eastern Amazon. MSc Thesis, School of Biological Sciences. Norwich, University of East Anglia, pp. 1-39.

Paolisso, M., Sackett, R., 1985. Traditional meat procurement strategies among the Irapa-Yukpa of the Venezuela-Colombia border area. Research in Economic Anthropology 7, 177-199.

Peres, C.A., 1990. Effects of hunting on western Amazonian primate communities. Biological Conservation 54, 47-59.

Peres, C.A., 2000a. Effects of subsistence hunting on vertebrate community structure in Amazonian Forests. Conservation Biology 14, 240-253.

Peres, C.A., 2000b. Evaluating the impact and sustainability of subsistence hunting at multiple Amazonian Forest Sites. In: Robinson, J.G, Bennett, E.L. (Eds.), Hunting for Sustainability in Tropical Forests. Columbia University Press, New York, pp. 31-56.

Peres, C.A., 2001. Synergistic effects of subsistence hunting and habitat fragmentation on Amazonian forest vertebrates. Conservation Biology 15, 1490-1505.

Peres, C.A., Janson, C., 1999. Species coexistence, distribution, and environmental determinants of neotropical primate richness: a community-level zoogeographic analysis. In: Fleagle, J.G., Janson, C., Reed, K.E. (Eds.), Primate Communities. Cambridge University Press, Cambridge, pp. 55-74.

Peres, C.A., Dolman, P., 2000. Density compensation in neotropical primate communities: evidence from 56 hunted and non-hunted Amazonian forests of varying productivity. Oecologia 122, 175-189.

Peters, R.H., 1983. The Ecological Implications of Body Size. Cambridge University Press, Cambridge.

Redford, K.H., Robinson, J.G., 1987. The game of choice: patterns of Indians and colonist hunting in the Neotropics. American Anthropologist $89,650-667$.

Reid, H., 1979. Some Aspects of Movement Growth and Change among the Hupdu Maku Indians of Brazil. PhD Thesis, Cambridge University, Cambridge.

Robinson, J.G., Bennett, E.L., 2000. Hunting for Subsistence in Tropical Forests. Columbia University Press, New York.

Romanoff, S.A., 1984. Matses Adaptation in the Peruvian Amazon. PhD Thesis, Columbia University, New York.

Ross, E.B., 1978. Food taboos, diet, and hunting strategy: the adaptation to animals in Amazon cultural ecology. Current Anthropology $19,1-36$.

Saffirio, G., Scaglion, R., 1982. Hunting efficiency in acculturated and unacculturated Yanomama villges. Journal of Anthropological Research 38, 315-327. 
Saffirio, J., Hames, R., 1983. The forest and the highway. Working Papers on South American Indians 6, 1-51.

Silverwood-Cope, P., 1972. A Contribution to the Ethnography of the Colombian Maku. PhD Thesis, Cambridge University.

Smith, N.J.H., 1976. Utilization of game along Brazil's transamazon highway. Acta Amazonica 6, 455-466.

Smith, R.J., Jungers, W.L., 1997. Body mass in comparative primatology. Journal of Human Evolution 32, 523-559.

Souza-Mazurek, R.R., Pedrinhi, T., Feliciano, X., Hilário, W., Gerôncio, S., Marcelo, E., 2000. Subsistence hunting among the Waimiri Atroari Indians in central Amazonia, Brazil. Biodiversity and Conservation 9, 579-596.

Sponsel, L.E., 1981. The Hunter and the Hunted in the Amazon: An Integrated Biological and Cultural Approach to the Behavioral Ecology of Human Predation. PhD Thesis, Cornell University.

Stanford, C.B., Bunn, H.T., 2001. Meat-Eating and Human Evolution. Oxford University Press, Oxford.

Stearman, A.M., 1990. The effects of settler incursion on fish and game resources of the Yuquí, a native Amazonian society of eastern Bolivia. Human Organization 49, 373-385.

Stearman, A.M., Redford, K.H., 1995. Game management and cul- tural survival: the Yuquí Ethnodevelopment Project in lowland Bolivia. Oryx 29, 29-34.

Suárez, E., Stallings, J., Suárez, L., 1995. Small-mammal hunting by two ethnic groups in north-western Ecuador. Oryx 29, 35-41.

Townsend, W.R., 2000. The sustentability of subsistence hunting by the Sirionó Indians of Bolivia. In: Robinson, J.G, Bennett, E.L. (Eds.), Hunting for Sustainability in Tropical Forests. Columbia University Press, New York, pp. 267-281.

Vickers, W., 1980. An analysis of Amazonian hunting yields as a function of settlement age. Working Papers on South American Indians 2, 7-29.

Vickers, W.T., 1991. Hunting yields and game composition over ten years in an Amazon Indian territory. In: Robinson, J.G., Redford, K.H. (Eds.), Neotropical Wildlife Use and Conservation. University of Chicago Press, Chicago, pp. 53-81.

Wright, S.J., Gompper, M.E., DeLeon, P., 1994. Are large predators keystone species in neotropical forests? The evidence from Barro Colorado Island. Oikos 71, 279-294.

Yost, J.A., Kelley, P.M., 1983. Shotguns, blowguns, and spears: the analysis of technological efficiency. In: Hames, R.B., Vickers, W.T. (Eds.), Adaptative Responses of Native Amazonians. Academic Press, New York, pp. 189-224. 